\title{
More than Most: Comparative Constructions in Muna
}

\author{
René van den Berg \\ SIL International
}

\begin{abstract}
Comparative constructions are an understudied field of research in the regional languages of Indonesia. This paper provides a detailed look at Muna, an Austronesian language of southeast Sulawesi, where there appears to be an unusually large assortment of comparative constructions and lexemes. These include the comparative, superlative and equative degree (all of which are expressed non-morphologically), correlative and 'let alone' constructions, as well as various inherently comparative lexemes. Of typological interest are the use of a comitative preposition for the standard marker, and the lack of a designated word meaning 'less'. The wealth of data available is possibly related to various aspects of the Muna culture, including the popularity of competitive games and the traditional social stratification.
\end{abstract}

\section{Introduction}

Muna is a Western Austronesian language spoken in southeast Sulawesi, Indonesia (see map 1 for the location of Muna in Indonesia). ${ }^{1}$ It is a member of the small Muna-Buton group, itself part of the larger Celebic group, which is a subgroup of Western Malayo-Polynesian. Muna is probably spoken by over 300,000 people, but the exact number of speakers is very difficult to ascertain. There has been considerable outmigration from the island of Muna to the provincial capital Kendari, as well as to other places in eastern Indonesia (Maluku, Papua), and these are not usually included in census figures. Also, there is considerable language shift to Indonesian. Traditionally this shift happened among urban and educated Muna people (especially in Kendari, but also in Raha, the capital of Muna), but it is now increasingly found across the whole island, due to widespread education in Indonesian and exposure to the media, specifically television. Many young people growing up on Muna only have a limited knowledge of their ancestral language.

\footnotetext{
${ }^{1}$ I would like to acknowledge some of the Muna friends who helped me to learn their intriguing language between 1985 and 1994: $\uparrow$ Nilus Larangka, $\dagger$ Hanafi, $\dagger$ La Ode Abdul Fattah, $\dagger$ La Ada, Syahruddin, as well as Lukas Atakasi for the southern dialect. More recently Mainuru Hado, La Habi, Lawa, Jafar and Dr La Aso have been very helpful in answering questions. I also want to thank the editors and two reviewers for their comments which led to many improvements.

The following glossing abbreviations are used in this paper: ACT.PART active participle, ADV adverb, APPL applicative, ART article, CAUS causative, CLAS classifier, DETR detransitivizer, DU dual, FEM feminine, FOC focus, EXC exclusive, FUT future, HON honorific, INC inclusive, IRR irrealis, LOC locative, MASC masculine, NEG negator, NMLZ nominalizer, OBJ object, PASS.PART passive participle, PAUS pausal clitic, PERF perfect, PL plural, POSS possessive, PRED predicative, PROH prohibitive, REAL realis, REC reciprocal, REDUP reduplication, SG singular, SU subject, SURPR surprisive, TOT totalizer, TR transitivizer. Circumfixes such as nominalizing $k a-\ldots-h a$ are glossed with identical glosses NMLZ for the prefixing and the suffixing part. Other abbreviations used: conj conjunction, k.o. kind of, lit. literally, n noun, s.o. someone, s.th. something, v verb, vi intransitive verb, vs stative verb, vt transitive verb; a-, ae- and ao- refer to three verbal inflection classes.
} 


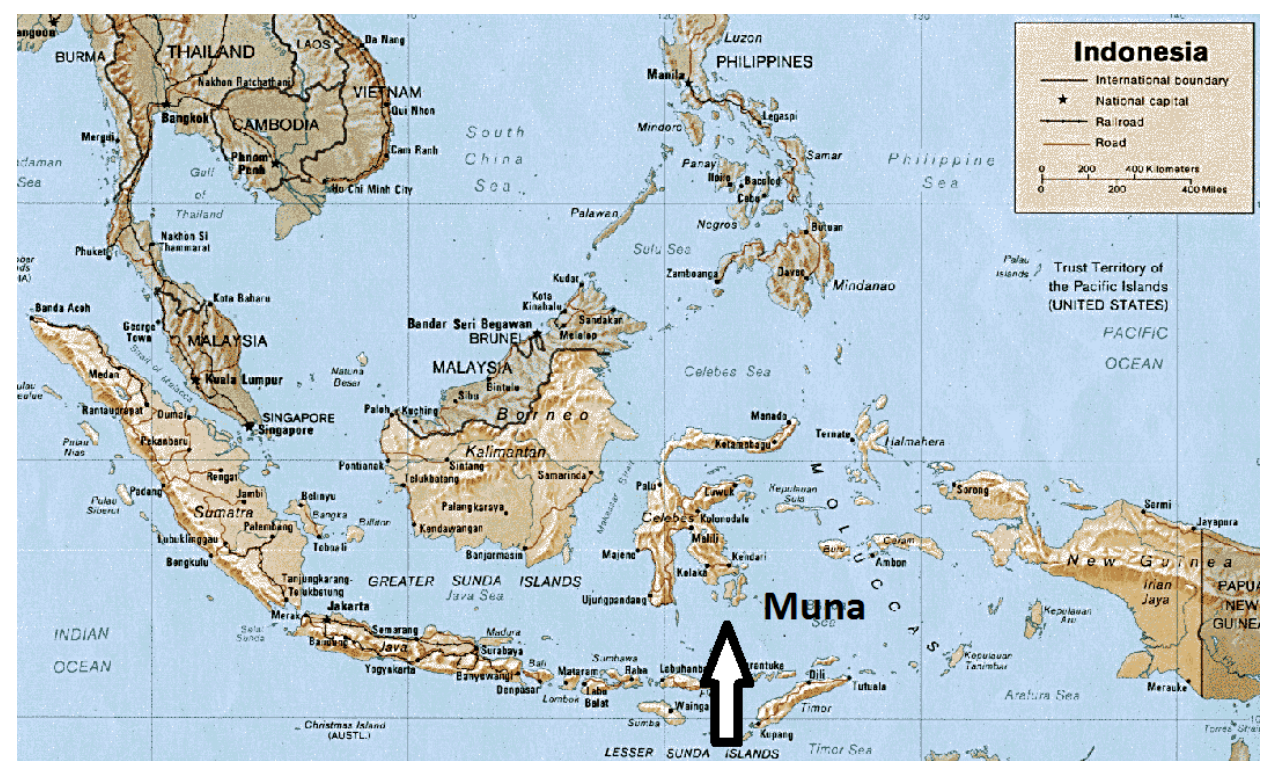

Figure 1. The Location of Muna in Indonesia

Typologically, Muna can be characterized as follows (see also van den Berg 1989).

The language has a relatively simple phonology of five vowels and 25 consonants, including seven prenasalized consonants, an implosive $/ 6$ / written as $<$ bh $>$, a voiced dental plosive $/ \mathrm{d} /$ written as $<\mathrm{dh}>$, and a voiced uvular fricative $/ \mathrm{b} /$ written as $<\mathrm{gh}>$. Syllable structure is (C) V and stress is penultimate.

Muna morphology is mostly agglutinative with a rich and diverse array of forms. Prefixation and suffixation are prevalent, but there is also infixation, circumfixation, reduplication and various combinations of these categories. Less common are compounding, incorporation and subtraction.

The major word classes are verbs and nouns, both of which have extensive morphological possibilities, especially verbs. Verbs are classified into three inflection classes $(a$-, $a e$ - and $a o$ class, based on the 1SG subject form; see Table 1 below). In addition, verbs are morphosyntactically grouped into a further three classes: stative (corresponding to adjectives ${ }^{2}$ ), dynamic (intransitive) and transitive. In the lexicon verbs are therefore specified for both their inflection class and their morphosyntactic class. Examples are late (vi,ae-) 'live' (meaning that late is an intransitive verb belonging to inflection class ae-) and lowu (vs,ao-) 'drunk' (meaning that lowu is a stative verb belonging to inflection class $a o-)$. Closed classes, most of which have few morphological possibilities, are pronouns, demonstratives, numerals and classifiers, quantifiers, adverbs, prepositions, conjunctions, particles and interjections.

Inflectional morphology centers around four person-number sets: subject prefixes, direct object suffixes and indirect object suffixes on verbs, as well as possessor/agent suffixes on nouns and passive participles (see Table 1). Each inflected verb is marked as either realis or irrealis. There is a distinct definiteness effect: definite objects cause a change in verbal inflection class from $a e$ - to $a-$.

Non-finite verb forms include active and passive participles. Verbal derivational morphology is broad, including a variety of valency-changing affixes, among others causative, transitivizing, reciprocal, detransitivizing, applicative, requestive, accidental/non-volitional passive, as well as various nominalizations. There is also considerable evaluative morphology.

\footnotetext{
${ }^{2}$ Muna does not have a separate word class of adjectives. Property words such as 'big' and 'new' are coded as stative verbs, receiving subject inflection when functioning as predicates. When they function attributively they are marked as participles in relative clauses or nominalized by means of $k a-$. See van den Berg (1989:45-47) for a full discussion.
} 


\begin{tabular}{|l|l|l|l|l|l|}
\hline \multicolumn{2}{|c|}{} & free & direct object & indirect object & possessor-agent \\
\hline \multirow{4}{*}{ SG } & 1 & inodi, idi & - -kanau & -kanau & -ku \\
\cline { 2 - 6 } & 2 & (i)hintu & - -ko & -angko & -mu \\
\cline { 2 - 6 } & 2 HON & intaidi & -kaeta & -kaeta & -nto \\
\cline { 2 - 6 } & 3 & anoa & - - & -ane & -no \\
\hline DU & 1 INC & intaidi & -- & -- & -nto \\
\hline \multirow{3}{*}{ PL } & 1 INC & intaidi-imu & -- & -- & -nto-omu \\
\cline { 2 - 6 } & 1 EXC & insaidi & -kasami & -kasami & -mani \\
\cline { 2 - 6 } & 2 & (i)hintu-umu & -ko-omu & -angko-omu & -Vmu \\
\cline { 2 - 6 } & 2 HON & intaidi-imu & -kaeta-amu & -kaeta-amu & -nto-omu \\
\cline { 2 - 6 } & 3 & andoa & - -da & -anda & -ndo \\
\hline
\end{tabular}

\begin{tabular}{|c|c|c|c|c|c|c|c|}
\hline & \multicolumn{6}{|l|}{ subject } \\
\hline & & \multicolumn{2}{|l|}{ class $a-$} & \multicolumn{2}{|l|}{ class $a e-$} & \multicolumn{2}{|l|}{ class ao- } \\
\hline & & realis & irrealis & realis & irrealis & realis & irrealis \\
\hline \multirow[t]{4}{*}{ SG } & 1 & a- & a- & ae- & ae- & ao- & ao- \\
\hline & 2 & o- & o- & ome- & ome- & omo- & omo- \\
\hline & $2 \mathrm{HON}$ & to- & ta- & te- & tae- & to- & tao- \\
\hline & 3 & no- & na- & ne- & nae- & no- & nao- \\
\hline $\mathrm{DU}$ & $1 \mathrm{INC}$ & do- & da- & de- & dae- & do- & dao- \\
\hline \multirow[t]{5}{*}{ PL } & $1 \mathrm{INC}$ & do-Vmu & da-Vmu & de-Vmu & dae-Vmu & do-Vmu & dao-Vmu \\
\hline & $1 \mathrm{EXC}$ & ta- & ta- & tae- & tae- & tao- & tao- \\
\hline & 2 & $\mathrm{o}-\mathrm{Vmu}$ & o-Vmu & ome-Vmu & ome-Vmu & omo-Vmu & omo-Vmu \\
\hline & $2 \mathrm{HON}$ & to- $\mathrm{Vmu}$ & ta-Vmu & te-Vmu & tae-Vmu & to-Vmu & tao-Vmu \\
\hline & 3 & do- & da- & de- & dae- & do- & dao- \\
\hline
\end{tabular}

Nouns are not marked for case or gender, and only marginally for number. The unmarked constituent order is VS in intransitive clauses and AVO in transitive clauses, though deviations are common for pragmatic reasons. SV, for example, is frequently encountered in intransitive clauses. The language is head-marking and uses prepositions. There is no voice marking in main clauses; the active-passive voice distinction is limited to relative clauses.

Dialectal variation of the language is extensive, especially in the southern half of the island, encompassing major phonological, morphological and lexical differences. The variety spoken in the northern half of the island is considered the prestigious dialect and is the basis for the data presented here. The few examples where I have used data from southern Muna are clearly indicated.

My own involvement with Muna goes back to 1985, when I started doing fieldwork on the island. This resulted in a grammar (van den Berg 1989), later followed by a Muna-English dictionary (van den Berg and La Ode Sidu 1996) and a Muna-Indonesian dictionary (La Ode Sidu and van den Berg 2000, rev. 2013). I have also published on other aspects of Muna, such as the southern dialect, spatial terminology, loanwords, and evaluative morphology, for which see the

\footnotetext{
${ }^{3}$ In Table $1 V$ in - $V m u$ stands for an echo-vowel. Even though all these pronominal affixes are bound elements, in the practical orthography used for Muna (and followed in this paper) the longer suffixes are written as separate words. The most common of these are -kanau '1SG.OBJ', -kasami '1PL.EX.OBJ', -kaeta '2SG.HON.OBJ' and -mani '1PL.EX.POSS.'
} 
references. The website www.bahasamuna.org makes many of these writings available and also offers some educational, textual and cultural materials.

This paper examines the rich variety of lexical and grammatical means for coding comparisons in Muna, a topic which has not yet been studied separately in any detail. It starts with the comparative $(\S 2)$, the superlative $(\S 3)$ and the equative degree $(\S 4)$. Then it moves on to inherently comparative lexemes $(\S 5)$, correlative constructions ( $(6)$, a 'let alone' construction $(\S 7)$, and the word labhi 'more' $(\S 8)$. In the final section $(\S 9)$, I try to link this profusion of comparative constructions to aspects of the Muna culture. A short conclusion ( $(10)$ summarizes the main findings and lists questions for further research.

The paper is not concerned with qualitative comparisons (similatives with 'like' and simulatives with 'as if'), which is another rich domain of research.

The data on which this study is based are mostly taken from a large text and dictionary corpus that was collected between 1985 and 1994, supplemented by additional examples obtained from translation work, conversations and e-mail exchanges.

\section{Comparative degree}

\subsection{Basic typology}

Muna does not make use of morphological comparatives to indicate relative superiority, as is the case in English (big-bigger). Instead, Muna has a dedicated construction, illustrated in (1).
$\begin{array}{llll}\text { (1) } & \text { No-bhala } & \text { anoa } & \text { bhe inodi. } \\ \text { 3SG.SU.REAL-big } & \text { 3SG } & \text { COM } & \text { 1SG }\end{array}$
'S/He is bigger than I am.'

In Dixon's (2012) typology of comparatives, Muna is a type A2 language:

- the comparee is a subject (anoa '3SG');

- the parameter is a stative verb (bhala 'big'; the prefix no- marks agreement with the subject);

- the standard is inodi ' $1 \mathrm{SG}$ ';

- the standard marker is the comitative preposition bhe 'with, and';

- there is no parameter marker in this construction (no word or affix corresponding to English more or -er; but see $\S 8$ on the word labhi 'more').

Other monoclausal examples, each showing exactly the same features, are (2)-(5).

(2) A-bhala inodi bhe hintu.

1sG.SU-big 1SG COM 2SG

'I am bigger than you are.'

(3) No-tugha kontu bhe wite.

3SG.SU.REAL-hard stone COM land/soil

'Stone is harder than soil.'

(4) No-wondu duria bhe nangka.
3SG.SU.REAL-fragrant durian COM jackfruit
'A durian smells better than a jackfruit.' 


(5) Do-pande andoa bhe intaidi ini.
3PL.SU.REAL-clever 3PL COM 1PL.INC this
'They are cleverer than we are.'

\subsection{Variations}

Some variations on this basic pattern are possible, discussed and illustrated below, although the exact conditions under which these variations occur are not yet fully understood.

Normally the comparee follows the stative verb functioning as the parameter, but in (6) the comparee subject precedes the verb to give it special prominence:
Ka-feghawu-ti-no
no-lea
bhe
ka-bhantofa-no.
NMLZ-abuse-TR ${ }^{4}$-3SG.POSS 3SG.SU.REAL-painful COM
'His abusive words hurt more than his slapping.'

Example (7) shows a topic-comment structure with the topic foo mani 'our mangoes' preceding the verb no-bhari 'many', and the comparee and the standard both in the form of active participles functioning as NPs.
(7)

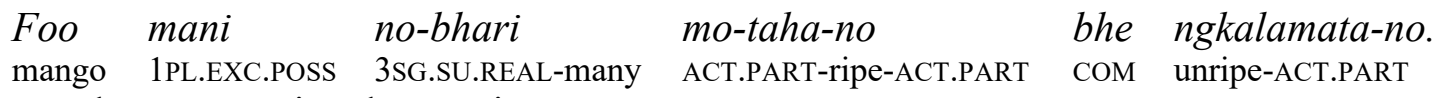
'We have more ripe than unripe mangoes.'
(Lit. 'Our mangoes, [there are] many ripe than unripe [ones].')

Example (8) is another topic-comment structure, but here the comparee is not a subject but a prepositional phrase following the idiom tai lalo 'be attached to, be emotionally close to' (lit. '[the] inside sticks'). The standard is also a PP (ne ina-no 'to its mother'), resulting in a sequence of two prepositional phrases.
(8)

$\begin{aligned} & \text { Ana-no no-tai } \\ & \text { child-3SG.POSS }\end{aligned}$ 3SG.SU.REAL-stick $\begin{aligned} & \text { lalo-no } \\ & \text { inside-3SG.POSS }\end{aligned}$ ne $\begin{array}{ll}\text { ama-no } & \text { bhe } \\ \text { father-3SG.POSS } & \text { COM }\end{array}$
ne ina-no.
LOC mother-3sG.POSS
'The child is more attached to its father than to its mother.'
(Lit. 'His/her child, its inside sticks [more] to its father than to its mother.')

Sometimes an argument is absent, as it can be understood from context. In (9), for example, the standard (the other participant in the race) is left implicit and hence there is no PP introduced by bhe 'with'. It is clear, however, that a comparative reading is intended given the presence of a dhuri 'referee'.
(9) Mahingga ne-rimba see-mie, ${ }^{5}$ o dhuri no-fo-puli-e although 3SG.SU.REAL-fast one-person ART referee 3SG.SU.REAL-CAUS-equal-3SG.OBJ 'Although one person was faster, the referee declared it a draw.'

\footnotetext{
${ }^{4}$ The intransitive verb feghawu means 'to use abusive language, to call names'. The nominalization with $k a$ - is derived from its transitive counterpart feghawu-ti 'to abuse s.o.'.

${ }^{5}$ The word see-mie 'a person' is a variant of the more common se-mie, found in (38).
} 
The parameter can also be modified by another verb, as no-tende 'it runs' does in (10), giving nerimba 'it is fast' an adverbial meaning. ${ }^{6}$

$\begin{array}{llll}\text { Ne-rimba } & \text { no-tende } & \text { rusa } & \text { bhe dahu. } \\ \text { 3SG.SU.REAL-fast } & \text { 3SG.SU.REAL-run } & \text { deer } & \text { cOM dog }\end{array}$

'A deer runs faster than a dog.' Or: 'Deer run faster than dogs.'

In (11), a sentence with a topicalised object, the comparee and the standard are both transitive verbs:

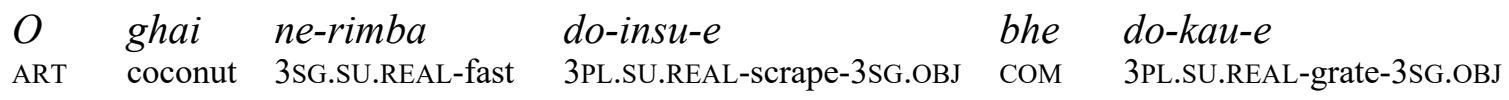

'It is quicker to scrape a coconut than to grate it.' Or: 'One scrapes a coconut quicker than one grates it.'(Lit. 'A coconut, it is fast [if] they scrape it than [if] they grate it.')

Verbal rather than nominal comparees are common in comparisons involving the verb asi-ghoo 'love, like' (the root asi 'love' with an obligatory applicative suffix -ghoo). In such comparative constructions, this verb is best translated as 'prefer', as in (12) and (13), the latter having a full clause as comparee and as standard.
No-asi-ghoo
ne-ninseleu
bhe ne-kawutu.
3SG.SU.REAL-love-APPL 3SG.SU.REAL-braid.hair
COM 3SG.SU.REAL-wear.hair.in.bun

'She prefers braiding her hair to wearing it in a bun.'

$\begin{array}{llllll}\text { No-asi-ghoo } & \text { no-fumaa } & \text { kambuse } & \text { bhe } & \text { no-fumaa } & \text { pae. } \\ \text { 3SG.SU.REAL-love-APPL } & \text { 3SG.SU.REAL-eat } & \text { cooked.maize } & \text { COM } & \text { 3SG.SU.REAL-eat } & \text { rice } \\ \text { 'He prefers eating maize to eating rice.' } & & & \end{array}$

\subsection{The standard marker bhe}

The comitative preposition bhe 'with', which is used for the standard marker in a comparative construction, has several additional functions in Muna. Its primary function is a coordinating conjunction 'and', linking nouns (ina-no bhe ama-no 'her/his mother and her/his father'), NPs, verbs and predicates. However, it is also found in in resultative, existential and exclamatory clauses, as illustrated in (14), (15) and (16).

$\begin{array}{llll}\text { No-bhari } & \text { no-fekiri } & \text { no-bungi } & \text { bhe fotu-no. } \\ \text { 3sG.SU.REAL-many } & \text { 3SG.SU.REAL-think } & \text { 3SG.SU.REAL-bald } & \text { COM }\end{array}$

'He thinks a lot, therefore he is bald.'

(Lit. 'It is much [that] he thinks, it is bald with his head.')

(15) Miina bhe doi ka-rubu-ku-a.

NEG COM money NMLZ- little-1SG.POSS-PAUS

'I don’t have any change.' (Lit. 'Not with my little money.')

${ }^{6}$ Even though ne-rimba 'it is fast' appears to modify no-tende 'it runs', it is actually the other way round: no-tende modifies ne-rimba. Without no-tende the clause means essentially the same thing ('A deer is faster than a dog'), but without ne-rimba the clause loses its comparative meaning and simply means 'a deer and a dog run/are running'. 


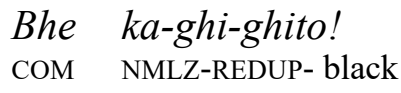

'How black s/he/it is!' (Lit. 'With blackness!')

For further discussion and examples of the multi-purpose preposition bhe, see van den Berg (1989:141-143).

Dixon (2012:352) remarks that especially ablative prepositions with the meaning 'from' are cross-linguistically common to serve as standard markers in a comparative construction. Muna does not have a specific preposition meaning 'from'; any of the local prepositions ne, we, te, as well as bhe can be translated as 'from' in the appropriate context. However, the use of a comitative preposition for the standard marker appears to be typologically unusual. Stassen (1985:36) mentions the occasional use of instrumental markers, comitative markers and benefactive markers, but does not cite specific languages for the comitative. I am only aware of two other languages that code the standard marker with a comitative preposition: Nuer (Nilo-Saharan; quoted in Ultan 1972) and Mongsen Ao (Sino-Tibetan; Coupe 2007) ${ }^{7}$, though it is likely that a more thorough search will yield further cases.

Since bhe can also mean 'and', this can in principle lead to structural ambiguity, as in (17), where the coordinated NP kawea bhe kaendo 'wind and waves' could theoretically also be interpreted as a comparison. In practice, such ambiguity appears to be very rare or non-existent.

Bhangka-ndo no-kalobu rampano no-ghosa $\quad$ kawea bhe kaendo.
boat-3PL.POSS 3SG.SU.REAL-capsize because 3SG.SU.REAL-hard wind COM wave
'Their boat capsized because the wind and the waves were strong.'
(Possible but unlikely meaning '... because the wind was stronger than the waves.')

\subsection{Alternatives}

There are two alternative ways of forming the comparative degree. One of these employs the word liu 'pass, surpass, exceed', to be discussed in more detail in $\S 3$ in relation to superlatives. The parameter is a nominalized stative verb, often affixed with a possessive suffix which indicates the comparee. The parameter marker is the transitive verb liu.
Ina-ku a-liu-e
ka-langke.
mother-1SG.POSS 1SG.SU-surpass-3SG.OBJ NMLZ-tall
'I am taller than my mother.' (Lit. 'My mother, I surpass her [in] tallness.')

It is not clear whether there is a semantic difference with the regular comparative construction with bhe. It should be noted that this construction is extremely rare in my text corpus, but is relatively

\footnotetext{
${ }^{7}$ Ultan (1972:53) lists two languages in his appendix that have "instr-com" markers for the comparative degree. One is presumably Nuer, but the second one remains unknown. Thanks to Yvonne Treis for bringing the languages in this section to my attention.
} 
frequent in translated material. An example from the southern dialect is $(19)^{8}$, which uses the variant foliu for standard Muna liu. ${ }^{9}$

Ka-ntuhu-no $\quad$ a-pesua ka-tohongku a-foliu-da.
NMLZ-often-3SG.POSS 1 1SG.SU-enter NMLZ-imprison 1SG.SU-surpass-3PL.OBJ
'I have been in prison more often than they.' (2 Corinthians 11:23)
(Lit. 'The oftenness/frequency I entered prison, I surpass them.')

Typically we find 3SG or 3PL possessors, on the nominalized stative verbs, as in (19). First and second person possessors in these constructions are absent from my corpus. The comparative with liu was also given in e-mail correspondence as a translation equivalent of the English comparative construction. Its almost complete absence from the large text corpus is puzzling. ${ }^{10}$

The second alternative to an unmarked comparative makes use of the word labhi 'more', a word which is discussed in more detail in $\$ 8$. Again, this construction is infrequent in my corpus, being limited to three examples. The first one occurs in translated material and is probably a calque from Indonesian.
Yakub
labhi no-asi-ghoo
Yusuf bhe
ana-no
Y. more 3SG.SU.REAL-love-APPL Y
COM child-3SG.POSS
sigaahano.

'Yakub loved Yusuf more than his other children.' (Genesis 37:3)

Structurally (20) is remarkably close to its Indonesian source text: [Yakub] lebih mengasihi Yusuf dari semua anak-nya yang lain $^{11}$ ([Yakub] more loved Yusuf from all his-children REL other), '[Yakub] loved Yusuf more than all his other children.' As outlined in $\S 8$, labhi is not normally used to code the comparative degree, and the combination of labhi with bhe is rare, but apparently well-understood.

The second and third example of labhi come from the dictionary corpus (van den Berg and La Ode Sidu 1996) and from a small corpus of traditional poetry respectively. In both cases there is a clear comparison, but the parameter is not a property concept. Rather, in (21) the comparee and the standard are both actions (expressed as clauses consisting of a verb and an adverb or an object NP), while in (22) they are persons. In both cases bhe $\sim$ bhae is the standard marker, and labhi is the parameter meaning 'it is better' (its literal meaning is 'more'; see also $\S 8$ for further discussion of labhi). Notice that (22) is shown to be poetry by the use of an archaic form (bhae instead of bhe), and spontaneous initial prenasalization (mpasole for pasole 'handsome' ${ }^{12}$; mpatida for patida 'type of spade, traditional iron tool for hoeing').

\footnotetext{
${ }^{8}$ Example (19) is taken from Bhihita Metaa. Podhandi'a Bu'ou, the New Testament in Muna (see alkitab.bahasamuna.org for the full text). It is unlikely that this is a calque from Indonesian, as Indonesian does not use a verbal construction to code the comparative. Instead it uses the adverbial parameter marker lebih 'more', as in lebih sering 'more often'.

${ }^{9}$ The variant is remarkable, as fo-liu (DETR-surpass) is normally a detransitivized form of liu 'surpass' used in superlatives (see §3). In this case, however, the object suffix - $d a$ clearly show that foliu is treated as a transitive verb in the southern dialect.

${ }^{10}$ It is possible that with a non-third person comparee, such as in (18) and (19), the alternative comparative degree with liu is the preferred, or even only, choice. I have not been able to verify this.

${ }^{11}$ Taken from the 1985 Indonesian Bible translation called Alkitab. Terjemahan Baru.

${ }^{12}$ The form pasole is the root form of the stative verb pasole 'handsome, beautiful'. Attributive root forms are not uncommon in poetry. The regular attributive form in normal conversation would be the active participle $<m>$ asoleno, with infix -um- (realized as nasal substitution) and suffix -no.
} 

Bhe ome-ngkoo-ngkora
ghulempesu,
labhi o-moghondo-ghoo
ina-mu.
COM 2SG.SU-REDUP-sit for.nothing better 2SG.SU-look-APPL mother-2SG.POSS

'Instead of just sitting there doing nothing, it is better to search your mother for lice.'
Bhae la-dhangka
mpasole labhi la-tongku
mpatida.
COM ART.MASC-young.man handsome better ART.MASC-carry.on.shoulder spade
'Instead of a handsome young man (as a suitor), it is better to have someone who carries a spade.'

This alternative construction with labhi and bhe seems to be the preferred way of coding a comparison between full clauses or between people.

\subsection{Inferiority}

Expressing relative inferiority ('less than') is problematic in Muna. Dedicated constructions involving relative inferiority have not been encountered in the corpus. There is no lexical item meaning 'less' and native speakers are often at a loss to find an equivalent of the Indonesian term kurang 'less'. It appears that native speakers simply circumvent this structural gap by expressing the situation in terms of relative superiority or non-equality. In other words, rather than saying 'My house is smaller than yours', Muna speakers would express this situation in their language as 'Your house is bigger than mine' or (culturally more appropriate) 'Our houses do not have the same size' or 'My house does not match yours.' ${ }^{3}$ This is further illustrated in (23), which was provided as the translation equivalent of 'La Remi is less tall than Wa Ati'. Instead of building a negative construction around the stative verb langke 'tall', a positive statement is made based on the antonym panda 'low, short'.

\begin{tabular}{|c|c|c|c|c|}
\hline Ne-panda & $L a$ & Remi & bhe & $W a$ \\
\hline 3SG.SU.REAL-low/short & ART.MASC & R. & $\mathrm{COM}$ & ART.FEM \\
\hline
\end{tabular}

There are, however, several lexical items in Muna which offer solace for this structural gap. There is, for instance, the intransitive verb kae meaning 'be not enough, be lacking, have a shortage', which can be used as the equivalent of Indonesian adverb kurang 'less'. However, kae always has absolute reference, and never involves an explicit comparison, as illustrated in (24).

$$
\begin{aligned}
& \text { Ane no-kae } \quad \text { ghoti, de-gana-gana } \\
& \text { if } \quad \text { 3SG.SU.REAL-not.enough food } \\
& \text { 'If there is not enough food, people have to economize on eating.' }
\end{aligned}
$$

This verb kae can be modified by a numeral phrase indicating the number or amount which is lacking, as in (25), from a text about growing maize, the traditional food crop on Muna. The numeral phrase raa wula 'two months' in combination with no-kae seendai (3SG.SU.REALnot.enough a.little) 'a bit short of', results in the meaning 'just a bit less than two months' or 'just a bit under two months'.

\footnotetext{
${ }^{13}$ The negative counterpart of a basic comparative (He is not bigger than you) also appears to be rare, but more research is needed to investigate this.
} 


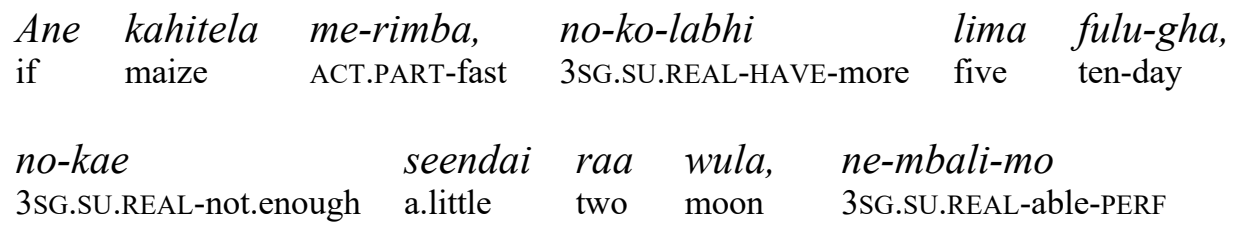

do-wulawo-e.

3PL.SU.REAL-harvest.preliminarily-3SG.OBJ

'As for fast-growing maize, after more than fifty days, just a bit less than two months, it can already be harvested in a preliminary fashion.'

The verb kae can also be negated, as in miina nao-kae (NEG 3SG.IRR-not.enough), meaning 'there is no shortage, nothing is lacking, it is enough.'

A second verb to express inferiority, specifically for amounts, is the use of the stative verb $n d a i$ 'be little' in a comparative construction, as in (26).
Doi-ku ne-ndai bhe doi-mu. money-1SG.POSS 3SG.SU.REAL-little COM money-2SG.POSS
'I have less money than you.' (Lit. 'My money is little than your money.')

In order to express inferiority with specific numbers or amounts, Muna can also use the verb pata 'be enough, sufficient, adequate', the positive counterpart of kae. This is most commonly found preceded by a negator, meaning 'not enough for, less than', as in (27). ${ }^{14}$

\begin{tabular}{|c|c|c|c|}
\hline$O$ & & $n a-<m>a t a^{15}$ & moghono \\
\hline OSS & & 3SG.SU.IRR- $<$ IRR $>$ enough & \\
\hline
\end{tabular}

'The distance is less than a hundred steps.'

(Lit. 'Its farness will not be enough [for] a hundred steps.')

An alternative to this construction is the use of the complex prepositional phrase we pandano (LOC lower.part-3sG.POss) 'under, less than', as in (28). The noun panda means 'the lower part, the area down below'.
Ta-karadhaa
we panda-no
tolu dhamu.
1PL.EXC.SU-work LOC lower.part-3sG.POSS three hour
'We worked less than (lit. under) three hours.'

\section{Superlative degree}

The superlative degree in Muna is illustrated in (29).

\footnotetext{
${ }^{14}$ Without the negator, pata is almost exclusively found in temporal clauses. An example is No-pata kaawu se-wula... (3SG.REAL-enough after one-moon) 'After a month had gone by...'.

${ }^{15}$ The irrealis verb form $<m>a t a$ shows nasal substitution; it is the surface realization of -um- 'irrealis' + pata 'enough'.
} 
$\begin{array}{lllllll}\text { Anoa } & \text { mie } & \text { fo-liu-no } & \text { ka-langke } & \text { ne liwu aini. } \\ \text { 3SG } & \text { person } & \text { DETR-surpass-ACT.PART } & \text { NMLZ-tall } & \text { LOC } & \text { village }\end{array}$

' $\mathrm{S} / \mathrm{He}$ is the tallest person in this village.'

(Lit. 'S/He [is] the person surpassing [in] tallness in this village.')

This construction consists of the following features:

- the comparee is the subject (anoa ' $3 \mathrm{SG}$ ');

- the parameter is a nominalized stative verb langke 'tall';

- the parameter marker is an active participle fo-liu-no '(the one) surpassing', which is based on the detransitivized verb fo-liu 'pass, surpass, exceed';16

- the PP ne liwu aini 'in this village' functions as the domain within which the statement is true.

Superlatives with similar constructions are further illustrated in (30) and (31):

$\begin{array}{lllll}\text { O } & \text { kahitela } & \text { no-pesua } & \text { kantisa } & \text { fo-liu-no } \\ \text { ART } & \text { maize } & \text { 3SG.SU.REAL-enter } & \text { crop } & \text { DETR-surpass-ACT.PART }\end{array}$

ka-bhari ne wite-no Wuna.

NMLZ-many LOC land-3sG.POSs Muna

'Maize is the most common crop on Muna.'

(Lit. 'Maize enters the crop which surpasses (others) [in] number in the land of Muna.')

(31) Anoa-mo itu robhine fo-liu-no ka-sangka welo wunta-wunta ini.

3SG-PRED that woman DETR-surpass-ACT.PART NMLZ-pretty in REDUP-middle this

'She is the prettiest woman among us.'

(Lit. 'She is the woman which surpasses (others) [in] prettiness in this middle.)'

The basic literal meaning of the intransitive verb liu is 'pass, pass by', as for instance a person or a car passing by on the road, a boat at sea, or birds in the air, as illustrated in (32):

$\begin{array}{lllll}\text { Ana sikola-hi sadhia do-liu } & \text { we } & \text { kolambu } & \text { mani. } \\ \text { child school-PL always 3PL.SU.REAL-pass } & \text { LOC } & \text { yard } & \text { 1PL.EXC.POSS }\end{array}$

'The pupils always pass by our yard.'

As mentioned before, the verb liu can also be used in a comparative sense, as in (18) and (19) above, though this appears to be a functionally marked construction.

If there is no standard, the meaning of no-fo-liu (3SG.SU.REAL-DETR-surpass) is elative 'exceedingly, extremely, very', as in (33) and (34):
Maka La
Ntaapo-apo
ini-a
no-fo-liu
ka-mambulega.
and ART.MASC N.
this-PAUS 3SG.SU.REAL-DETR-surpass NMLZ-lazy
'And La Ntaapo-apo was extremely lazy.' (Not: '... was the laziest')

\footnotetext{
${ }^{16}$ The detransitivising prefix $f_{o}$ - is added to transitive verbs. A human object is implied, but left implicit. Often this is the first person plural inclusive, as in the following statement about a dog: no-fo-sia (3SG.REAL-DETR-bite) 'it bites us/people'.
} 

Garaa ini o mie
moghane,
bhe ka-pasole
no-fo-liu.
SURPR this ART person man COM NMLZ-handsome
3SG.SU.REAL-DETR-SUrpass

'But it was actually a man, and he was exceedingly handsome.'

The word order in the second part of (34) is unusual. A more regular order would be no-fo-liu kapasole (3SG.SU.REAL-DETR-surpass NMLZ-handsome) 'most handsome', as in (33). It is probable that bhe in (34) is actually an exclamatory bhe, also illustrated in example (16), which would be an alternative explanation for the following nominalization and the marked word order. It is possible that non-3SG forms such as a-fo-liu (1SG.SU-DETR-surpass) 'I surpass others; I am the best', can also be used as elatives, but this remains to be investigated as they do not occur in my corpus.

Finally, there is one clear example in the corpus of a superlative meaning without the use of fo-liu-no (DETR-surpass-ACT.PART), illustrated in (35).

$\begin{array}{llllll}\text { Do-po-mansitiki, } & \text { hamai } & \text { bhari-no } & \text { peni } & \text { aitu-e-mo } & \text { fo-talo-no. } \\ \text { 3PL.SU.REAL-PLAY-baseball } & \text { which } & \text { many-ACT.PART } & \text { point } & \text { that-FOC-PRED } & \text { DETR-defeat-ACT.PART }\end{array}$
'In baseball, whoever scores the most points is the winner.'

(Lit. '[When] they play baseball, which/whoever [has] many points, that one is [the one] who defeats people.'

It is possible that this is limited to the root bhari 'many.' Depending on the context the active participle bhari-no can mean 'many', 'more' or 'most'.

\section{Equative degree and sameness}

Muna has two main ways to express the equative degree:

- the intransitive verb pototo 'be the same';

- repeated nominalization.

\subsection{The verb pototo 'be the same'}

The most unmarked way of expressing the equative degree is by means of the intransitive verb pototo 'be the same', followed by a nominalized stative verb. Example (36) illustrates a simple clause with the verb pototo, not involving an equative degree (which needs a stative verb), but simply an identical referent. Examples (37), (38) and (39) illustrate equative degrees with nominalized stative verbs. Notice that the unreduplicated base pototo has dual reference (though the subject prefix is singular for non-humans). When there are more than two human participants involved, the root is reduplicated to pototo-toto ${ }^{17}$ and has a plural subject prefix, as in (38) and (39). The parameter, the nominalized stative verb, agrees with the plural subject and receives a plural possessive suffix.

\footnotetext{
${ }^{17}$ Although the form pototo-toto appears to be a case of suffixing reduplication (same-REDUP), all reduplication in Muna is prefixing, hence the gloss REDUP-same in (38) and (39). Prefixing reduplication is shown by such examples as intara 'hold' + po- 'reciprocal' > po-intara 'hold each other (dual)' and po-inta-intara 'hold each other (plural)'. It appears that for reduplicative purposes pototo is treated as a bimorphemic stem with a prefix po-: po-toto, hence the reduplicated form po-toto-toto, rather than the expected *poto-pototo. It is possible that pototo 'same' is historically related to the noun toto 'direction, side towards', in combination with the reciprocal prefix po-.
} 


$\begin{array}{lllll}\text { Ne-fumaa-no } & \text { sapi } & \text { no-pototo } & \text { bhe } & \text { karambau. } \\ \text { PASS.PART-eat-3SG.POSS } & \text { cow } & \text { 3SG.SU.REAL-same } & \text { cOM buffalo }\end{array}$

'Cows eat the same food as buffaloes.'

(Lit. 'What is eaten by cows is the same as buffaloes.')

Sau aini bhe sau aitu no-pototo ka-wanta-no.

wood this COM wood that 3SG.SU.REAL-same NMLZ-long-3SG.POSS

'This piece of wood and that piece of wood (near you) are equally long.'

(Lit. '... its length is the same.')

$\begin{array}{llll}\text { Ka-kesa-ndo } & \text { do-pototo-toto } & \text { pada } & \begin{array}{l}\text { se-mie. } \\ \text { one-person }\end{array}\end{array}$

'They were all equally beautiful.' (Lit. 'Their beauty was the same [for] each person.')
Ka-rimba-ndo do-tende
do-pototo-toto
ka-to-tolu-ha-ndo.
NMLZ-fast-3PL.POSS 3PL.SU.REAL-run
3PL.SU.REAL-REDUP-Same TOT-REDUP-three-TOT-3PL.POSS
'All three of them ran equally fast.'
(Lit. 'The speed of their running was the same [for] all three.'

\subsection{Repeated nominalization}

An alternative and less frequent strategy to express the equative degree is to create an equational clause (a simple juxtaposition of noun phrases), in which the nominalized stative verb is repeated, occurring both in the subject and the predicate. This is illustrated in (40) and (41); it so happens that the stative verb used (rimba 'fast') is identical in these two examples, but there do not appear to be constraints on the verbal root.
(40)
$\begin{array}{lllll}\text { Ka-rimba-no } & \text { no-horo } & \text { katogha, } & \text { ka-rimba-no } & \text { dua } \\ \text { NMLZ-fast-3SG.POSS } & \text { 3SG.SU.REAL-fly } & \text { crow } & \text { NMLZ-fast-3SG.POSS } & \text { also }\end{array}$
dahu no-lumpa.
dog 3SG.SU.REAL-run
'The dog ran as fast as the crow flew.' 18
(Lit. 'The speed of the crow flying [was] the speed of the dog running.')

Example (41) is taken from a story about a boy who gets advice from an elder on how to outwit a monster by magically flying away.

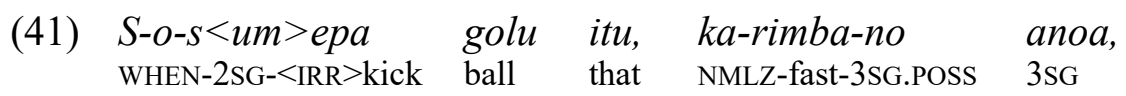

soo-mo ka-rimba-mu dua.

FUT-PRED NMLZ-fast-2SG.POSS also

'As soon as you kick the ball, you will go as fast as it goes.'

(Lit. 'When you kick the ball, the speed of it, that will also be your speed.')

\footnotetext{
${ }^{18}$ An alternative translation 'The crow flew as fast as the dog ran' is possible, but since the dog is the topic in this section of the narrative, the most natural translation equivalent has the dog in sentence-initial position.
} 


\subsection{Other ways to mark sameness}

In addition to these equative degrees, Muna has other means to express sameness or equality. One of these is the verbalizing prefix si-followed by a noun, either a simple or a derived noun. The meaning of the resulting verb is 'be one in respect to X; have the same X; be of the same X; share $\mathrm{X}$ '. The subject prefix is always plural, but with non-reduplicated base nouns, the subject has dual reference. With reduplicated base nouns, the reference is plural, as illustrated in (42):

\begin{tabular}{|c|c|c|c|}
\hline ta-si-guru & 'we (DU.EXC) have the same teacher' & guru & 'teacher' \\
\hline ta-si-guru-guru & 'we (PL.EXC) have the same teacher' & & \\
\hline ta-si-kakuta & 'we (DU.EXC) are siblings' & kakuta & 'sibling' \\
\hline ta-si-kaku-kakuta & 'we (PL.EXC) are siblings' & & \\
\hline do-si-lambu & $\begin{array}{l}\text { 1.'we (DU.INC) have the same house' } \\
\text { 2.'they (DU) have the same house' }\end{array}$ & lambu & 'house' \\
\hline do-si-ama & $\begin{array}{l}\text { 1.'we (DU.INC) have the same father' } \\
\text { 2.'they (DU) have the same father' }\end{array}$ & ama & 'father' \\
\hline do-si-bhasitie & $\begin{array}{l}\text { 1.'we (DU.INC) are relatives' } \\
\text { 2.'they (DU) are relatives' }\end{array}$ & bhasitie & 'relatives' \\
\hline do-si-kae-late-ha & $\begin{array}{l}\text { 1.'we (DU.INC) live in the same place' } \\
\text { 2.'they (DU) live in the same place' }\end{array}$ & kae-late-ha & $\begin{array}{l}\text { 'living } \\
\text { place' }\end{array}$ \\
\hline do-si-funu-funua & $\begin{array}{l}\text { 1.'We (PL.INC) belong to the same group' } \\
\text { 2.'they (PL) belong to the same group' }\end{array}$ & funua & 'group' \\
\hline do-si-kao-kao-lodo-ha & $\begin{array}{l}\text { 1. 'we (PL.INC) share a bed' } \\
\text { 2.'they (PL) share a bed' }\end{array}$ & kao-lodo-ha & 'bed' \\
\hline
\end{tabular}

Additionally, Muna has various specific lexemes with a meaning component indicating sameness or equality, listed in (43). The first three verbs (obligatorily reduplicated) are completely synonymous (though the first one is the most common), and have a cross-temporal perspective on sameness. They are also unusual in that they use object suffixes to refer to the single verbal argument, as illustrated in (44).
adho-adho (vi,a-) 'be still the same, remain unchanged'
hula-hula (vi,a-) 'be still the same, remain unchanged'
sadaa-daa (vi,a-) 'be still the same, remain unchanged'
endengi (vt)
'be the same as, be equal, be in harmony with'
fotete
'remain the same towards, occupy the same location'
rasi
(n)
'sameness, equality, likeness'

Three of these lexical items are illustrated in the following clauses. The preposition peda 'like' in (44) is the normal preposition to indicate similarity, as, for example in peda inodi (like 1SG) 'like me' or peda dahu (like dog) 'like a dog'.

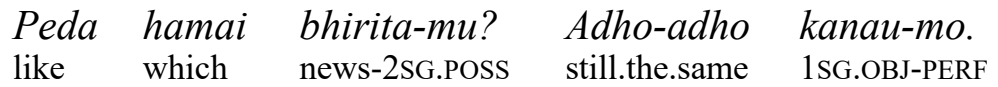

'How are you doing?' (Lit. 'Like which [is] your news?')

'Fine, the same as before.' Or: 'I'm still the same.' 

Miina dae-fotete
se-ghonu
lambu.
not 3PL.SU.IRR-remain.the.same one-CLAS house

'They did not remain in the same house.'

(Lit. 'They did not remain the same [with regard to] one house.')

(46)
rasi-no
ama-no,
anahi-hi-no
3SG.SU.REAL-take
sameness-3SG.POSS
father-3sG.POSS
wife-PL-3SG.POSS
do-ru-dua dua.
3PL.SU.REAL-REDUP-two also
'He did the same thing as his father did, he also had two wives.'
(Lit. 'He took the sameness of his father, his wives [were] also two.')

It is noteworthy that the word $d u a$ 'also' occurs quite frequently in equative and sameness constructions, as in (40), (41) and (46). This is hardly surprising, as dua 'also' has an inherent additive meaning component, but the exact conditions under which dua needs to be present or can be left out remain to be explored.

\section{Inherently comparative lexemes}

Dixon (2012:365) mentions the presence of "inherently comparative lexemes" in some languages, in which the parameter and the parameter marker are fused, like English prefer. Muna has a fairly large group of such inherently comparative lexemes, most of which are verbs, with a few nouns and one idiom. These are listed in (47).

\begin{tabular}{|c|c|c|}
\hline feisa & $(v i, a-)$ & 'be older than' (cf. isa 'older sibling') \\
\hline feai & $(\mathrm{vi}, \mathrm{a}-)$ & 'be younger than' (cf. $a i$ 'younger sibling') \\
\hline fosibhala & $(\mathrm{vt}, \mathrm{ae}-)$ & 'consider more important, emphasize' (cf. bhala 'big') \\
\hline netaa & (vi,ae-) & $\begin{array}{l}\text { 1. 'it is good' } \\
\text { 2. 'it is better; it is best' }\end{array}$ \\
\hline ghindulu & (vi,a-) & $\begin{array}{l}\text { 'go first, do s.th. first, be earlier than others' (also } \\
\text { uninflected in compounds or serial constructions) }\end{array}$ \\
\hline aliha & (n) & 'a better idea' (with possessive suffixes) \\
\hline dhulu-dhulu & (vi,ae-) & 'increasingly, more and more, Adj-er and Adj-er' \\
\hline hende & $(\mathrm{vi}, \mathrm{a}-)$ & $\begin{array}{l}\text { 1. 'move up, go forward, progress' } \\
\text { 2. 'rise, increase, become more' }\end{array}$ \\
\hline ano & $\begin{array}{l}\text { (idiom) } \\
\text { (adv) }\end{array}$ & $\begin{array}{l}\text { 'what is unsurpassed, the very best thing, what outweig } \\
\text { 'even more so, all the more so' }\end{array}$ \\
\hline
\end{tabular}

That these lexemes are inherently comparative is shown by the fact that in each case there is a comparison between more than one entity, or a comparison of qualities (though sometimes one of the entities can be left implicit). The fact that translations of these lexemes in Indonesian include words such as lebih 'more', paling 'most' and semakin 'increasingly' (or their English equivalents) corroborates this analysis.

The following clauses illustrate several of these lexemes. Notice that in examples (48) to (51) the standard is introduced by the preposition bhe, just as it is in regular comparative degree constructions. The other examples illustrate different types of inherently comparative lexical items, both syntactically and semantically. 
(48)

No-feisa se-taghu bhe inodi.

3SG.SU.REAL-be.older one-year COM 1SG

'She is one year older than I am.'

$\begin{array}{lllll}\text { Ana-ku } & \text { no-feai } & \text { raa } & \text { gholeo } & \text { bhe ana-mu. } \\ \text { child-1SG.POSS } & \text { 3SG.SU.REAL-be.younger } & \text { two } & \text { day } & \text { COM child-2SG.POSS }\end{array}$

'My child is two days younger than yours.'
No-fosibhala
bhaindo bhe
wuto-no.
3SG.SU.REAL-consider.important others COM self-3SG.POSS

'He considers other people more important than himself.'

$\begin{array}{lll}\text { (51) No-gaa } & \text { ghindulu } & \text { bhe inodi. } \\ \text { 3sG.SU.REAL-marry } & \text { go.earlier } & \text { COM } 1 \mathrm{SG}\end{array}$

'He married earlier than I did.'

Koe-mo anoa, sewaliha-ku ihintu.

PROH-PERF 3SG a.better.idea-1SG.POSS 2SG

'Not him/her, I think it is better if you do it.'

(Lit. 'Do not him/her, my better idea [is] you.')

(53)

Umuru-ndo ne-dhulu-dhulu ka-kamokula.

age-3PL.POSS 3SG.SU.REAL-REDUP-increase NMLZ-old

'They grew older and older.' (Lit. 'Their age increased [in] oldness.')

(54)

$\begin{array}{llll}\text { Ai-no } & \text { no-sungku, } & \text { nihompu } & \text { isa-no, } \\ \text { younger.sibling-3SG.POSS } & \text { 3sG.SU.REAL-naughty } & \text { the.more } & \text { older.sibling-3sG.POSS }\end{array}$

no-sungku sepaliha.

3SG.SU.REAL-naughty very

'The younger brother is naughty, but the older brother even more so, he is very naughty.' (Lit. His/her younger sibling is naughty, the more [so] his/her older sibling, s/he is very naughty.')

\section{Correlative comparisons}

Muna has at least two correlative constructions, that is, constructions in which two comparative clauses are juxtaposed, like the English example 'The smaller it is, the faster it goes'. As in English, these are balanced constructions in Muna, the two clauses each being introduced by the same adverb. In the first type the adverb is nihompu 'the more' (or its stylistic variants hompu, nihompuи, nehompu ${ }^{19}$ ). Example (55) is from a text on traditional musical instruments and describes the making of a xylophone and the type of wood that one should use. ${ }^{20}$

\footnotetext{
${ }^{19}$ It is possible that nihompu is historically multimorphemic, but the origin of the word is not known.

${ }^{20}$ The instrument under discussion is a katou, a xylophone consisting of several loose pieces of wood (between 3 and 7), placed in a row on the upper legs and played with two sticks, while the player sits with outstretched legs. This instrument, like many traditional instruments, is now rarely found on Muna.
} 

Nihompu
no-kele,
nihompu no-kesa
ndii-no.
the.more 3SG.SU.REAL-dry the.more 3SG.SU.REAL-beautiful
sound-3SG.POSS
'The drier it (the wood) is, the more beautiful its sound.'

The following example, (56), is from a story about a competition among food crops as to who will be their leader. Rice turns out to be the best candidate to become king of the foods. He is praised for his humble character in the following way:

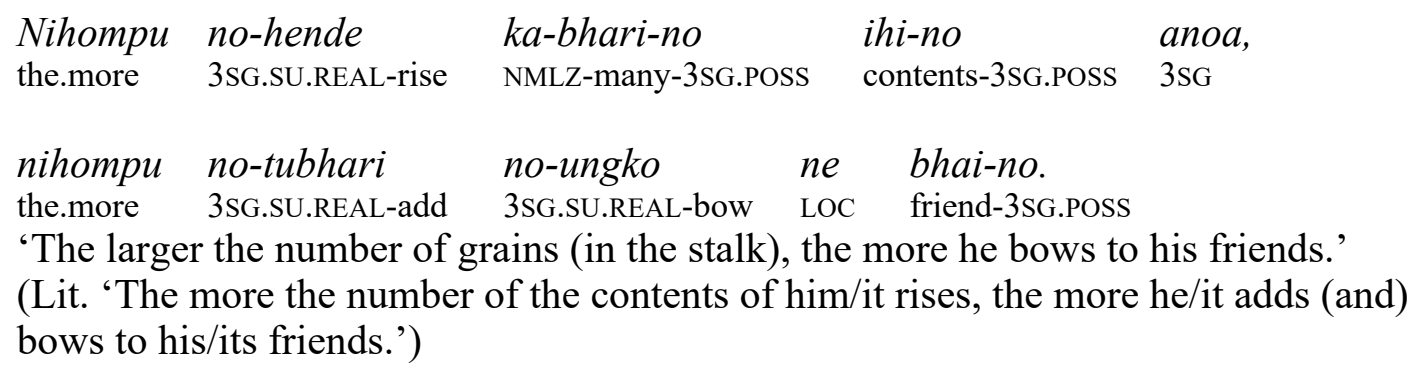

The second type of correlative comparison is similar, except that the adverb is the deverbal word hende 'the more' (from the intransitive verb hende 'move up, go forward, rise, increase'), and that in both clauses hende is followed by a nominalized stative verb. There does not appear to be any semantic difference between the use of hende and nihompu.
Hende ka-maho, hende ka-bhala. the.more NMLZ-near the.more NMLZ-big
'The closer it came, the bigger it was.'

\begin{tabular}{|c|c|c|c|c|c|c|c|c|c|}
\hline $\begin{array}{l}O \\
\text { ART }\end{array}$ & $\begin{array}{l}\text { sapi } \\
\text { cow }\end{array}$ & $\begin{array}{l}<\text { um }>\text { ona } \\
\text { ACT.PART }>\text { g }\end{array}$ & $\begin{array}{l}\text { caught-ACT.P } \\
\text { che }\end{array}$ & & $\begin{array}{l}\text { ne } \\
\text { LOC }\end{array}$ & & & $\begin{array}{l}\text { hende } \\
\text { the.more }\end{array}$ & $\begin{array}{l}\text { ka-ghosa } \\
\text { NMLZ-hard }\end{array}$ \\
\hline $3 \mathrm{SG}$ & $\begin{array}{l}\text { inta, } \\
\text { U.REAL-pull }\end{array}$ & $\begin{array}{l}\text { hende } \\
\text { the.more }\end{array}$ & $\begin{array}{l}\text { ka-gehe } \\
\text { NMLZ-tight }\end{array}$ & & & $\begin{array}{l}n e \\
\text { LOC }\end{array}$ & & $\begin{array}{l}\text { ghe-no. } \\
\text { SSG.POSS }\end{array}$ & \\
\hline
\end{tabular}

'When a cow is caught in a snare, the stronger it pulls, the tighter the rope gets around its legs.'

Correlative constructions are fairly uncommon cross-linguistically (Dixon 2012: 368), though Indonesian also has them, formed with makin 'the more', as in makin lama makin banyak (the.more long the.more many) 'the longer the time, the greater the amount'. I am not aware of other Sulawesi languages for which correlative comparisons have been reported.

\section{7. 'Let alone' construction}

Another construction which involves explicit comparison between entities is the so-called 'let alone' construction. The English 'let alone' construction has received considerable attention in recent years, primarily from a pragmatic and constructionist perspective (Fillmore et al. 1988, Verhagen 2005). In this section I simply add another specimen to the growing corpus of 'let alone' constructions, disregarding further semantic and pragmatic aspects.

'Let alone' is used in Muna (as it is in other languages) to emphasize the obvious impossibility of something, in comparison to another entity. It means that if statement $\mathrm{A}$ is true for entity $\mathrm{X}, \mathrm{A}$ 
is even more true for entity $\mathrm{Y}$. This should have been obvious to the addressee, as $\mathrm{A}(\mathrm{Y})$ is more complex or less expected than $\mathrm{A}(\mathrm{X})$. Some English examples are: He can't boil potatoes, let alone cook a full meal; I barely know the streets in my own village, let alone in the provincial capital.

In Muna this construction is also bipartite, though the second part is typically just a noun phrase, introduced by a complex conjunction. Semantically, the first clause makes a statement of negative character (though not necessarily a negative clause), which is even more true for the second clause. The first clause is sometimes introduced by the conjunction salangimo 'whereas, while' or one of its many stylistic variants: sangi, silangi, sangiha(mo), saniha(mo), sangihano(mo), sanihano(mo) or sinomo. Typically, the second clause is introduced by the complex conjunction poolimo dua, glossed as 'let alone' (poolimo is actually an uninflected form of the verb pooli 'can, be able', probably acting as an imperative here; dua means 'also, too'). Some examples:

\begin{tabular}{|c|c|c|c|c|}
\hline$O$ & $\begin{array}{l}\text { kaawu } \\
\text { only }\end{array}$ & $\begin{array}{l}\text { miina } \\
\text { not }\end{array}$ & $\begin{array}{l}\text { da-maa } \\
\text { 3PL.SU.IRR-give.IRR }\end{array}$ & $\begin{array}{l}\text { kanau, } \\
\text { 1SG.OBJ }\end{array}$ \\
\hline
\end{tabular}

'They did not give me anything; let alone you.'

$\begin{array}{llll}\text { Insaidi } & \text { kamokula } & \text { tao-tehi } & \text { tae-kala-kala } \\ \text { 1PL.EXC } & \text { old } & \text { 1PL.EXC.SU-afraid } & \text { 1PL.EXC.SU-REDUP-go }\end{array}$

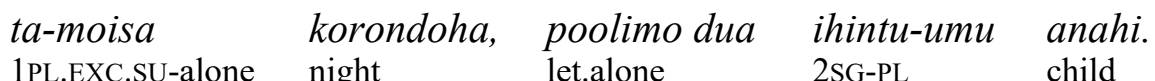

'We elders are afraid to walk by ourselves at night; let alone you children.'

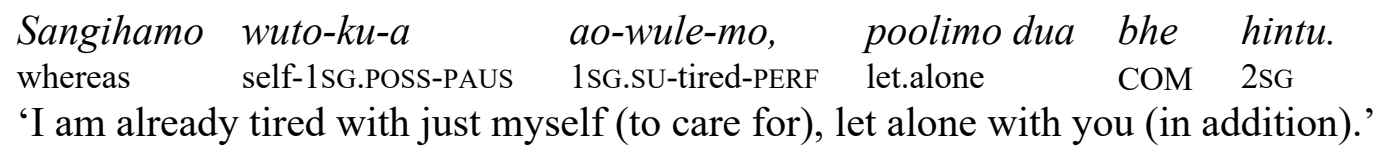

Example (62) is somewhat unusual, as the two clauses are reversed, the conjunction poolighoomu 'whereas' replaces the expected sangihamo, and instead of poolimo dua the author uses taamoolimo dua.
Ta- $a<m>$ ooli-mo
dua
hintu,
poolighoomu
wuto-ku
JUST-1SG.SU $<$ IRR $>$ can-PERF also
2SG
whereas
self-1SG.POSS

no-hali-mo.

3SG.SU.REAL-difficult-PERF

'How can I help you? It is difficult enough for me by myself.'

Or: 'I can just barely scrape by on my own, let alone with you in addition.'

\section{The word labhi 'more'}

There is one word in Muna which is deeply connected with comparisons: the word labhi 'more' and its derivations, already briefly introduced in $\$ 2.4$. Example (63), a slightly edited entry from the Muna dictionary (van den Berg and La Ode Sidu 1996), lists the main meanings, followed by a few illustrative examples. 
(63) labhi

1. (vi,a-; adv) more, more than, over (as a verb often followed by a number or number phrase; as an adverb following a number or number phrase)

2. (vi,a-) too much, profuse, extreme

3. (adv) (it is) better, (one had) better

4. (n) remainder, left-over, surplus

O anahi we sikola no-labhi moghono.

ART child LOC school 3SG.SU.REAL-more hundred

'There are more than one hundred pupils in the school.'

Doi-no $\quad$ ompulu riwu labhi.
money-3sG.POSs ten
'S/He has more than 10,000 rupiah.'

$\begin{array}{lll}\text { Do-fo-baru-baru } & \text { kampufu- } n d o, & \text { rampano } \\ \text { 3PL.SU.REAL-CAUS-REDUP-happy } & \text { youngest.child-3PL.POSS } & \text { because }\end{array}$

no-labhi ka-asi-ghoo-ndo.

3SG.SU.REAL-too.much NMLZ-love-APPL-3PL.POSS

'They are spoiling their youngest child, because they love/favor him/her too much'

(67) Labhi $a-s<u m>u l i-m o$.

better $\quad 1 \mathrm{SG}-<\mathrm{IRR}>$ go.home-PERF

'It is better for me to go home.'

$\begin{array}{lllll}\text { Labhi-no } & \text { sau } & \text { kae-katondo-ha } & \text { mbali } & \text { tumpu. } \\ \text { remainder-3SG.POSS } & \text { wood } & \text { NMLZ-make.fence-NMLZ } & \text { for } & \text { firewood }\end{array}$

'The wood left over from building the fence will be used as firewood.'

(Lit. 'The remainder of the fence-making wood [is] for firewood.')

Even though Muna labhi is a direct reflex from the Proto-Austronesian noun *labiq 'excess, surplus' (Blust and Trussell n.d.), it is possible that some of the meanings and constructions above may have been influenced by Indonesian lebih 'more'. This could include the unusual position of the adverbial labhi following numerals, as illustrated in (65), which follows the Indonesian pattern sepuluh ribu lebih (ten thousand more) 'more than ten thousand'.

The word labhi is also the base for a large number of derivations. These are listed below in (69), followed by a few examples illustrating the derivation ko-labhi 'be more than', which is the most relevant to the present discussion. Even though the translation of ko-labhi is 'be more than', the prefix ko- in ko-labhi is glossed as 'HAVE', on the basis of other similar derivations with this very productive prefix (e.g. doi 'money', ko-doi 'to have money').

(69) labhi-ha-ku more-ADV-1SG.POSS

labhi-ha-no

more-ADV-3SG.POSS (adv) 'I had better, according to me it is better' (variants: bhihaku, silabhihaku, bhehaku, labhehaku, selabhehaku)

(adv) '(it is) better' (variant: se-labhi-ha-no) 


\begin{tabular}{|c|c|}
\hline $\begin{array}{l}\text { fo-labhi } \\
\text { DETR-more }\end{array}$ & (vi,ae-) 'excessive, abnormal, extreme' \\
\hline $\begin{array}{l}\text { ka-labhi-a } \\
\text { NMLZ-more-NMLZ }\end{array}$ & (n) 'superiority, glory, divine power' \\
\hline $\begin{array}{l}\text { feka-ka-labhi-a } \\
\text { CAUS-NMLZ-more-NMLZ }\end{array}$ & (vt,ae-) 'make superior, glorify, exalt' \\
\hline $\begin{array}{l}\text { ko-labhi } \\
\text { HAVE-more }\end{array}$ & (vi,a-; adv) 'be more than' \\
\hline
\end{tabular}

ponta-labhi-labhi

(vi,a-) 'more than normal, abundantly, profusely'

RANDOM-REDUP-more

(70)

$\begin{array}{lllll}\text { Ka-bhari } & \text { mani } & \text { ta-ko-labhi } & \text { lima } & \text { fulu. } \\ \text { NMLZ-many } & \text { 1PL.EXC.Poss } & \text { 1PL.EXC.SU-HAVE-more } & \text { five } & \text { ten }\end{array}$

'There were more than fifty of us.' (Lit. 'Our number, we were more than fifty.')

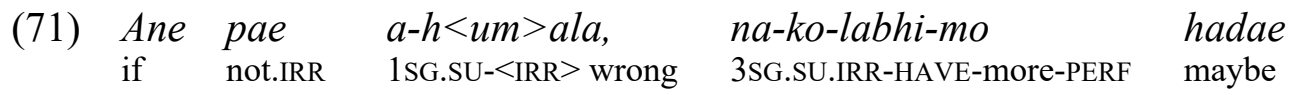

na-se-wula-a.

IRR-one-month-PAUS

'If I am not mistaken, it might already be more than a month ago.'

$\begin{array}{lllll}\text { Ka-langke-no } & \text { fointo } & \text { beano } & \text { ko-labhi } & \text { se-inere. } \\ \text { NMLZ-tall-3sG.POSS } & \text { door } & \text { must } & \text { HAVE-more } & \text { one-height.of.person }\end{array}$

'The height of a door has to be more than that of a person standing up.'

\section{Correlating language and culture: comparing and competing in Muna culture}

In this section, following a suggestion in Dixon (2012), I try to correlate the wealth of comparative constructions in Muna described above with lexical and cultural aspects of games and competition. Dixon observes:

Across the world, many societies — both large and small — are imbued with the notion of competition. This can be related to races or other sports, or just to prowess in daily activities. One person tries to be better than another, to win. Naturally there is then an appropriate stock of lexemes: 'race', 'compete', 'win', 'lose', 'victor', 'victory' and so on. In contrast, there are many small egalitarian communities — including both Dyirbal and Jarawara — for which ideas of competition, or winning, or triumphing, are totally alien. They simply lack such lexemes.

This may also have consequences within the grammar. [...] Languages whose speakers indulge in competition are likely to use a grammar that includes a specific comparative construction... (Dixon 2012:441) 
Muna appears to be a solid example illustrating this possible relationship. In addition to several dedicated comparative constructions, Muna also has a considerable number of lexical terms dealing with competing, scoring points, winning, losing, and drawing. This, in turn, can be linked to the popularity of traditional (and modern) competitive games, and the occurrence of competitive story elements in folktales. A well-developed decimal counting system and a socially layered society complete the picture of a society where unequality and competition were, and still are to some extent, rife. The following section, which is preliminary in nature, lists a number of lexical and cultural elements in these domains that may shed some light on Dixon's tentative correlation. Whether this correlation is real or imaginary must remain an open question at this point, but the facts appear to be pointing in this direction.

Below is a tentative list of lexemes dealing with comparing, competing, winning, losing and drawing.

(73)

pototo-ane ${ }^{21}$
dhalu
po-dhalu
po-tandingi
po-tandingi-ha
po-udhi-ghoo
puli

fo-puli

fo-ala

peni

gele $\sim$ golo $\sim \operatorname{logo}$

po-gele $\sim$ po-golo $\sim$ po-logo

talo

fo-talo

ka-talo

ka-fo-talo

manangi

palili

soori

manan-soori

tampe (vt,a-) 'to compare'

(vt,ae-) 'to defeat'

(vi,a-) (REC-defeat) 'to compete, to race'

(vi,a-) (REC-compete) 'to compete with'

(n) (REC-compete-NMLZ) 'competition'

(vi,a-) (REC-test-APPL) 'to test each other'

(vi,a-) 'to be equal, be a match'

(n)

(vt,ae-) (CAUS-draw) 'to make it a draw, declare it a draw'

1. (vi,a-) (DETR-take) 'to score points, win'

2. (vt,ae-) (CAUS-take) 'to allow s.o. to win'

(n)

(vt,ae-)

(vi, a-)

1. (vi,ao-)

2. (vt,ae-)

$(\mathrm{vi}-, \mathrm{a}-)$

(n)

(n)

(vi,a-)

(vi,a-)

(vt,ae-)

$(\mathrm{vs}, \mathrm{a}-)$

(vi,a-) 'point scored in a game'

'to beat s.o. by finishing first in a race, race for s.th.' (REC-beat) 'to compete, try to be first'

'to lose, be defeated'

'to defeat s.o.'

(DETR-defeat) 'to win, be victorious'

(NMLZ-lose) 'loss, defeat'

(NMLZ-DETR-defeat) 'victory'

'to be superior, be sure to win'

'to always win (of cocks in fighting)'

'to defeat, overpower'

'to be always eager to win'

'to be even, be equal, be the same, draw (in business or in games)'

Keeping track of points in a game is never an issue. Muna has a robust decimal system with basic term for one to $\operatorname{ten}^{22}$, and additional terms for hundred (moghono), thousand (se-riwu), ten thousand (se-lasa) and a million (se-juta), of which only the latter two appear to be borrowed.

\footnotetext{
${ }^{21}$ The stem of this verb is pototo 'be the same', but with indirect object inflection (here represented by $3 \mathrm{SG}-$ ane) it means 'to compare'.

${ }^{22}$ The basic terms are 1 ise, 2 rua, 3 tolu, 4 paa, 5 lima, 6 noo, 7 pitu, 8 oalu, 9 siwa, 10 ompulu, all directly inherited from Proto-Austronesian. Each of these occur in three shapes: free, prefixed, and reduplicated, as for example for 4: paa, fato- and po-paa. The prefixed forms higher than two are written as separate words.
} 
In (74) a small selection of traditional games played by children in premodern times is presented. Most of these games, possibly more than thirty in total, are no longer played and were already obsolete in the early 1990s when these terms were collected. The following five terms (taken from Van den Berg and La Ode Sidu 1996, slightly edited) are all intransitive verbs using the prefix po-. This prefix, used for playing games and for playing instruments, could be termed a "luditive" prefix (it also has a reciprocal function). ${ }^{23}$
po-ase
po-bhanga
'play tag: one party runs to cross a line, the opponents try to tag them' po-bhanga 'play a game in which nuts are put in a wide circle drawn on the ground, then they are hit with other nuts; the purpose is to knock the nuts outside the circle, while the nuts used to hit them remain inside'
po-bheka 'play cat and mouse: a game in which a 'cat' and a 'mouse' are blindfolded, and the cat searches for the mouse who claps his or her hands' po-bunsu 'play top'
po-sepa 'play takraw (football with a rattan ball; several players stand in a circle and the ball is passed from one to another)'

Traditionally, competitions were also organized around groups asking each other riddles ( $p o-$ watangke), as well as cockfighting (po-sawu) and horsefighting (po-gira-ghoo adhara). Muna was, in fact, quite well-known for its horsefighting competitions, and national dignitaries or foreign tourists can still request such an event to be organized (at a considerable price).

Modern games that are regularly played on Muna include the following (each again with the "luditive" prefix po-). Most of these were introduced during the Dutch colonial period on Muna (1906-1949) and many, if not all, of the nominal roots are borrowings.

(75)-bhaguli
po-caturu
po-damu
po-foli
po-gata
'play marbles'
'play chess'
'play draughts'
'play volleyball'
'play with elastic bands'

There is also quite a variety of lexemes relating to card games, including po-baralaa 'play a card game where four players each hold four cards', po-kalawara 'play clubs' (from Dutch klaver). Modern competitions on Muna (and in Indonesia as a whole) also include more serious activities in the fields of education and religion, including the following:

- competition for the highest grades in a class (ranked class position for pupils);

- competition for "model pupil" and "model teacher";

- church choir competitions;

- Quran recitation competitions.

Much energy and money is spent on organizing and participating in these events at various levels (village, district, province, nation).

Muna folktales, reflecting a culture where competing is firmly embedded, also contain various competition narratives, especially when a big and strong animal is pitched against a smaller animal that is able to outsmart him. Here are some examples:

\footnotetext{
${ }^{23}$ The prefix po- does not simply have a collective meaning. For this function Muna uses the circumfix si-...-ha, as in kala 'go' > ta-si-kala-ha 'we (dual exclusive) go/went together.'
} 
- A buffalo and a snail hold a running competition, which the snail wins.

- A mousedeer and a genie hold a competition who can stay awake the longest.

- A finch and a buffalo hold a drinking competition, a kicking competition and a stonecrushing competition. In each case the finch outwits the buffalo.

As far as Muna society is concerned, traditionally it was very non-egalitarian, being divided into four strata, each one having specific rights, responsibilities and limitations. The first stratum was the high nobility (kaomu), followed by the low nobility (walaka). The majority of the populace belonged to the commoners (maradika), while a small section was treated as slaves (ghata). This social stratification determined not only the governing, judicial and religious positions one could fulfill, but also one's dress, where one could live, whom one could marry, the height of the bride price, mode of transportation, and how one or one's wife was to be addressed and referred to, among other things.

Given this non-egalitarian organization, it comes as no surprise that there was considerable strife and competition for the three top positions in the kingdom, the kingship and the two defense ministerial posts. Couvreur records several power struggles in the $19^{\text {th }}$ century.

Tying language to culture is fraught with problems, and we should refrain from making broad or speculative statements. However, the least one can say is that competition was (and is) firmly embedded in Muna culture. The linguistic cornucopia surrounding comparisons does therefore not come as a surprise.

\section{Conclusion}

The Muna language does not have a morphological comparative, superlative or equative degree, comparable to English big-bigger-biggest and Indonesian ter-besar 'biggest' or se-besar 'as big as'. Muna is, however, very rich in comparative constructions: it has dedicated comparative, superlative, equative and correlative constructions, a 'let alone' construction, and various inherently comparative lexemes, including the word labhi 'more'. The use of the comitative preposition bhe for the standard marker is typologically unusual. The preponderance of comparative constructions and lexemes may possibly tie in with the prevalence of competition in the culture, as shown by the popularity of traditional and modern competitive games. The social stratification may also have played a role.

A few follow-up research questions suggest themselves. The exact division of labor between the two strategies for the comparative degree needs further investigation, as well as possible semantic distinctions between alternative constructions and lexemes. More can possibly be said about the expression of relative inferiority and the use of $d u a$ 'also'. There is also a need to study comparative constructions in other languages of Sulawesi. Is the situation in Muna representative for other Celebic languages? In addition, a diachronic perspective on the comparative constructions and lexemes would be very welcome. So far, there is little evidence of borrowing.

\section{References}

Blust, Robert and Steven Trussell. n.d. The Austronesian Comparative Dictionary. Web edition. www.trussel2.com/ACD/ (Accessed 16 October 2015).

Coupe, Alexander R. 2007. A grammar of Mongsen Ao. Berlin: Mouton de Gruyter. 
Couvreur, J. 2001. Sejarah dan Kebudayaan Kerajaan Muna [History and Culture of the Muna Kingdom]. Kupang: Artha Wacana. [Original Dutch title Ethnografisch overzicht van Moena, 1935.]

Dixon, R.M.W. 2012. Basic linguistic theory. Volume 3: Further grammatical topics. Oxford: Oxford University Press.

Fillmore, Charles J., Paul Kay, and Mary Catherine O’Connor. 1988. Regularity and idiomaticity in grammatical constructions: the case of let alone. Language 64: 501-538.

Stassen, Leon. 1985. Comparison and universal grammar. Oxford: Blackwell.

Ultan, Russell. 1972. Some features of basic comparative constructions. Working Papers on Language Universals (Stanford) 9: 117-162.

van den Berg, René. 1989. A grammar of the Muna language. Dordrecht: Foris.

van den Berg, René. 1991. Muna dialects and the Munic languages: towards a reconstruction. VICAL 2. Western Austronesian and Contact Languages. Papers from the Fifth International Conference on Austronesian Linguistics, ed. by Ray Harlow, 21-51. Auckland: Linguistic Society of New Zealand.

van den Berg, René. 1991. Muna historical phonology. Studies in Sulawesi linguistics. Part II, ed. by J.N. Sneddon, 1-28. Jakarta: Badan Penyelenggara Seri Nusa, Universitas Katolik Indonesia Atma Jaya. NUSA volume 33.

van den Berg, René. 1995. Forestry, injections and cards: Dutch loans in Muna. Tales from a concave world. Liber amicorum Bert Voorhoeve, ed. by Connie Baak, Mary Bakker and Dick van der Meij, 191-215. Leiden: Projects Division Department of Languages and Cultures of South-East Asia and Oceania.

van den Berg, René. 1995. Verb classes, transitivity and the definiteness shift in Muna: A counterexample to the transitivity hypothesis. Oceanic Linguistics 34/1:161-190.

van den Berg, René. 1997. Spatial deixis in Muna (Sulawesi). Referring to space. Studies in Austronesian and Papuan languages, ed. by Gunter Senft, 197-220. Oxford: Clarendon Press.

van den Berg, René. 2004. Notes on the southern Muna dialect. Papers in Austronesian subgrouping and dialectology, ed. by John Bowden and Nikolaus P. Himmelmann, 129-169. Canberra: Pacific Linguistics.

van den Berg, René. 2015. Muna. Edinburgh Handbook of Evaluative Morphology, ed. by Nicola Grandi and Lívia Körtvélyessy, 367-374. Edinburgh: Edinburgh University Press

van den Berg, René and La Ode Sidu. 1996. Muna-English dictionary. Leiden: KITLV Press.

van den Berg, René and La Ode Sidu. 2000. Kamus Muna-Indonesia. Kupang: Artha Wacana Press. [2 $2^{\text {nd }}$ edition 2013, Yogyakarta: Pustaka Puitika].

Verhagen, Arie. 2005. Constructions of intersubjectivity: discourse, syntax, and cognition. Oxford: Oxford University Press. 